\title{
Screening rhizobacteria for biological control of Fusarium root and crown rot of sorghum in Ethiopia
}

\author{
H. Ahmed Idris ${ }^{a, b}$, N. Labuschagne ${ }^{a}$ and L. Korsten ${ }^{a}$ \\ ${ }^{a}$ Department of Microbiology and Plant Pathology, Forestry and Agricultural \\ Biotechnology Institute (FABI), University of Pretoria, Pretoria 0002, South Africa \\ ${ }^{b}$ Department of Biology, Alemaya University, Box 138, Diredawa, Ethiopia
}

\section{Abstract}

Fusarium oxysporum Schlectend causes root and crown rot in several crops including sorghum that results in low grain yield in Ethiopia and other East African countries. Seventy-eight bacterial isolates were obtained and subsequently tested both in vitro and in the greenhouse. Of the 78 isolates tested, 23 displayed between 30 and $66.3 \%$ inhibition of in vitro mycelial growth of $F$. oxysporum and also showed significant root colonization ability on sorghum seedlings. These isolates were further tested for their biocontrol ability against F. oxysporum in the greenhouse. Four isolates viz. KBE5-7, KBE5-1, KBE2-5 and NAE5-5 resulted in 100\% disease suppression and no symptoms of root and crown rot were observed compared to the control. The complete suppression of F. oxysporum by these isolates was also confirmed by root plating on Fusariumselective medium. The most effective isolates were identified by means of the API system as members of the Genus Bacillus including B. cereus, B. subtilis, B. circulans, B. licheniformis and B. stearothermophilus. Two other isolates, which colonized the sorghum rhizosphere and resulted in more than $70 \%$ disease suppression, have been identified as Chromobacterium violaceum. The study demonstrated effective biological control by the rhizobacterial isolates tested, thereby indicating the possibility of application of rhizobacteria for control of soilborne diseases of sorghum in Ethiopia and other countries. 


\section{Article Outline}

1. Introduction

2. Materials and methods

2.1. Soil sample collection and analysis

2.2. Isolation of bacteria

2.3. Bacterial inoculum preparation

2.4. In vitro antagonistic activity

2.5. In vitro root colonization

2.6. Greenhouse evaluation of rhizobacterial isolates

2.6.1. Pathogenecity tests and fungal inoculum preparation

2.6.2. Planting of sorghum and inoculation of fungal and bacterial isolates

2.6.3. Disease assessment

2.6.4. Incidence of Fusarium oxysporum in roots

2.6.5. Rhizosphere colonization

2.6.6. Identification of the bacterial isolates

2.6.7. Statistical analysis

3. Results

3.1. In vitro assays

3.2. Greenhouse experiment

3.3. Identification of bacterial isolates

4. Discussion

References

\section{Introduction}

Sorghum (Sorghum bicolor (L.) Moench) is ranked second among the five most important crops in East Africa (Food Agricultural Organization, 1999) and it is a staple food crop in arid and semi-arid areas in Ethiopia. The crop grows under a wide range of ecological conditions and is drought tolerant. Production is, however, very low in this country because of, amongst other factors, diseases caused by phytopathogenic fungi. 
Symptoms such as seedling death and root rot a few weeks after planting are commonly observed in the major sorghum fields.

Several members of the Genus Fusarium cause root diseases in sorghum leading to serious yield losses. Among the major pathogens in this group are Fusarium oxysporum Schlectend, F. moniliforme J. Sheld, F. graminearum Schwabe and F. tricinctum (Corda) Sacc. (Forbes et al., 1986). Most of the fungal pathogens reported on sorghum are found predominantly in Ethiopia and other East African countries (Huluka and Else, 1992).

In Ethiopia, repeated attempts have been made to control Fusarium root rot in sorghum with fungicidal treatments using, amongst others, benomyl. However none of the fungicides used have been successful mainly because of their phytotoxicity (Benhamou, 1992). Chemical control of sorghum diseases is also unaffordable in most developing countries. The use of broad-spectrum fungicides further results in imbalances within the microbial community creating unfavorable conditions for the activity of beneficial organisms (Villajuan-Abgona et al., 1996).

Soilborne diseases have been controlled more recently by means of certain beneficial bacteria that are indigenous to the rhizosphere of plants (Thomshaw, 1996). The rhizosphere, representing the thin layer of soil surrounding plant roots and the soil occupied by the roots, supports large and metabolically active groups of bacteria (Villacieros et al., 2003) known as plant growth promoting rhizobacteria (PGPR) (Kloepper et al., 1980). PGPR are known to rapidly colonize the rhizosphere and suppress deleterious microorganisms as well as soilborne pathogens at the root surface (Rangajaran et al., 2003). These organisms can also be beneficial to the plant by stimulating growth (Bloemberg and Lugtenberg, 2001).

Currently there is very limited knowledge regarding the biological suppression of Fusarium root and crown rot in sorghum by the application of PGPR in Ethiopia. The aim of this study is therefore to isolate bacteria from the sorghum rhizosphere and screen the organisms for in vitro and in vivo antagonistic activity against $F$. oxysporum, one of the major causes of root rot in Ethiopia. This study may contribute to the introduction of PGPR systems in biological control of phytopathogenic fungi in sorghum and other crops in Ethiopia. 


\section{Materials and methods}

\subsection{Soil sample collection and analysis}

In December 2004, a total of nine soil samples were collected from the rhizosphere of sorghum in two fields in Ethiopia, namely Meeson and Jijiga. Both areas are located in the Eastern part of the country where sorghum is commonly produced as a staple crop. These sites were selected because the soils have been previously cropped for at least 20 years with sorghum, maize and teff (Eragrostis teff), an indigenous crop of the grass family commonly used as a staple crop in the Northern and Central Ethiopia. Farming practices in these fields include fungicide sprays with benomyl and metalaxyl. After harvest, the remaining stubble is ploughed into the soil. Five collection sites in Meeson and four collection sites in Jijiga were selected and carefully marked before sample collection. Sorghum roots were uprooted and $1 \mathrm{~kg}$ rhizosphere soil was carefully transferred into sterile plastic bags before they were transported to the Microbiology Laboratory, Alemaya University, Ethiopia for isolation of bacteria. The soil particle size varies among the nine samples. This ranges from 18 to $61.2 \%$ for coarse sand, 11.5 to $37.7 \%$ for silt, and 21.8 to $61.1 \%$ for clay. All the soil samples in general have a larger proportion of Calcium $(\mathrm{Ca})$ ranging from 838 to $8830 \mathrm{mg} / \mathrm{kg}$ followed by magnesium $(\mathrm{Mg})$, potassium $(\mathrm{K})$, and sodium $(\mathrm{Na})$ ranging from 191 to $1079 \mathrm{mg} / \mathrm{kg}, 88$ to $583 \mathrm{mg} / \mathrm{kg}$, and 20 to $88 \mathrm{mg} / \mathrm{kg}$, respectively. The least detected inorganic component was phosphorous (P) and this ranged from 0.1 to $1 \mathrm{mg} / \mathrm{kg}$.

\subsection{Isolation of bacteria}

Each soil sample was mixed before $1 \mathrm{~g}$ was transferred to $9 \mathrm{ml}$ quarter strength sterile Ringer's (Merck, Halfway house, South Africa) solution and was serially diluted. A $0.1 \mathrm{ml}$ aliquot of the serially diluted suspension was spread-plated on King's B medium (King et al., 1954) and nutrient agar (NA) medium (Biolab, Wadesville, South Africa) in triplicate. The spread-plate cultures were incubated for $24 \mathrm{~h}$. at $28{ }^{\circ} \mathrm{C}$. Ten to fifteen representative colonies, with different morphological appearances, were selected from the countable plates and re-streaked on a new plate but of the same media to obtain pure colonies. A total of 142 isolates originally obtained in this manner were maintained on agar slants and transported to the Plant Pathology Laboratory at the Department of 
Microbiology and Plant Pathology, University of Pretoria, South Africa. Because many isolates were morphologically indistinguishable in culture, preliminary characterization procedures included the following tests: Gregorson's KOH (Gregorson, 1978), cytochrome oxidase (Kovacs, 1956), oxidation fermentation (Huge and Leifson, 1953), catalase and motility tests. A total of 78 isolates were selected from the original 142 isolates. Soils were chemically analysed for their content of inorganic elements in the soil analysis laboratory of the Department of Plant Production and Soil Sciences, University of Pretoria, South Africa.

\subsection{Bacterial inoculum preparation}

Isolates were grown in nutrient broth (BioLab, Wadesville, South Africa) on a rotary shaker (LABOTECH) at $28{ }^{\circ} \mathrm{C}$ and $180 \mathrm{rpm}$ for $24 \mathrm{~h}$. The suspension was centrifuged (Avanti TM J-25 Beckman centrifuge) in $50 \mathrm{ml}$ capacity sterile plastic tubes at $5000 \mathrm{rpm}$ for $10 \mathrm{~min}$. The pellets were re-suspended in quarter strength sterile Ringer's (Merck) solution to give a final concentration of $10^{8} \mathrm{cfu} / \mathrm{ml}(\mathrm{OD}=0.5)$ at $550 \mathrm{~nm}$ using the viable plate count method and optical density measurement.

\subsection{In vitro antagonistic activity}

The in vitro inhibition of mycelial growth of $F$. oxysporum by the bacterial isolates was tested using the dual culture technique as described by Paulitz et al., 1992 and Landa et al., 1997. Three $50 \mu \mathrm{l}$ drops from the $10^{8} \mathrm{cfu} / \mathrm{ml}$ suspension were equidistantly placed on the margins of potato dextrose agar (PDA) (BioLab) plates and incubated at $28{ }^{\circ} \mathrm{C}$ for 24 h. A $4 \mathrm{~mm}$ agar disc from fresh PDA cultures of F. oxysporum was placed at the centre of the PDA plate for each bacterial isolate and incubated at $27 \pm 1{ }^{\circ} \mathrm{C}$ for seven days. The radii of the fungal colony towards and away from the bacterial colony were measured. The percentage growth inhibition was calculated using the following formula:

$$
\text { \& Inhibìion }=\left[\frac{(R-v)}{R} \times \operatorname{Ino}\right]
$$

where, $r$ is the radius of the fungal colony opposite the bacterial colony and, $R$ is the maximum radius of the fungal colony away from the bacterial colony. 
All isolates, which resulted in more than 30\% mycelial growth inhibition against the selected pathogen and/or which colonized the sorghum roots at a level higher than $10^{5} \mathrm{cfu} / \mathrm{cm}$ roots in the in vitro experiments were stored in nutrient broth supplemented with $15 \%$ glycerol at $-70{ }^{\circ} \mathrm{C}$.

\subsection{In vitro root colonization}

The isolates, which showed antagonistic activity in the dual culture assays, were tested for their ability to colonize sorghum roots in vitro, using a modification of the methods by Patten and Glick, 2002 and Montealegre et al., 2003. Sorghum seeds (South African variety Gewoon) were surface sterilized with $70 \%$ ethanol for $5 \mathrm{~min}$ and subsequently with $1 \%$ sodium hypochlorite for $1 \mathrm{~min}$ and rinsed three times in sterile distilled water. For each treatment, 15 seeds were transferred to a sterile moist chamber i.e. discs of filter paper placed in $90 \mathrm{~mm}$ diameter plastic Petri dishes and moistened with sterile distilled water. For inoculation, the bacterial inoculum was prepared as described above. A $1 \mathrm{ml}$ aliquot of each inoculum was added to the seeds in the moist chamber and the plates were incubated at room temperature for $1 \mathrm{~h}$ to allow binding of the bacteria to the seed coat. Both treated seeds and controls were then incubated at $30^{\circ} \mathrm{C}$ for $4-5$ days in the dark for root development. One centimeter of root from each treatment was aseptically excised, one seed per treatment, and transferred to $0.1 \mathrm{M} \mathrm{MgSO}_{4}$ solution, shaken and serially diluted. From each dilution, a $0.1 \mathrm{ml}$ aliquot was plated on King's B and NA media and the plates were incubated at $30{ }^{\circ} \mathrm{C}$ for colony counts. The number of bacteria colonizing the root was calculated as colony forming units/cm root (cfu/cm root).

\subsection{Greenhouse evaluation of rhizobacterial isolates}

\subsubsection{Pathogenecity tests and fungal inoculum preparation}

Fusarium oxysporum isolate RC331, F. oxysporum isolate SC134, F. verticilloides isolate RA145 and F. equiseti isolate RB125 isolated from infected sorghum roots were obtained from the University of the Free State, Bloemfontein, South Africa. Pathogenecity of the isolates were confirmed under greenhouse conditions. Based on the observation of visual stunting, root and crown rot and death of young seedlings, F. oxysporum isolate RC3B1 was selected as the most virulent isolate and was used as the target pathogen in this 
experiment. Millet seed (Panicum miliaceum L.) inoculum was prepared as follows: $150 \mathrm{~g}$ millet seed, together with $200 \mathrm{ml}$ distilled water was deposited in an autoclavable polyethylene bag and autoclaved at $121{ }^{\circ} \mathrm{C}$ for $15 \mathrm{~min}$. Each bag was subsequently inoculated with five $4 \mathrm{~mm}$ agar discs cut from a fresh PDA culture of $F$. oxysporum. The inoculum was incubated at $27 \pm 1{ }^{\circ} \mathrm{C}$ for 7 days.

\subsubsection{Planting of sorghum and inoculation of fungal and bacterial isolates}

All bacterial isolates which rendered more than $30 \%$ inhibition of $F$. oxysporum mycelial growth in the in vitro assay and which showed effective root colonization (beyond $10^{4} \mathrm{cfu} / \mathrm{cm}$ root) were selected for the in vivo evaluation in the greenhouse. Sorghum seeds were surface sterilized with $70 \%$ ethanol for $5 \mathrm{~min}, 1 \%$ sodium hypochlorite for $1 \mathrm{~min}$ and rinsed five times with sterile distilled water. The seeds were then pregerminated in sterile vermiculite for four days at $30{ }^{\circ} \mathrm{C}$ in a growth cabinet. Prior to seedling transplanting, the millet seed inoculum of $F$. oxysporum was mixed into steampasteurized soil in $12 \mathrm{~cm}$ by $10.5 \mathrm{~cm}$ diameter plastic pots at the rate of $30 \mathrm{~g} / \mathrm{kg}$. For the control treatments, sterile millet seed was mixed into the soil at the same rate. Eight sorghum seedlings were transplanted into each pot and the pots were maintained in the greenhouse at $30 \pm 1{ }^{\circ} \mathrm{C}$. One day after transplanting of seedlings, each pot was drenched with $30 \mathrm{ml}$ of each of the bacterial inocula $\left(10^{8} \mathrm{cfu} / \mathrm{ml}\right)$. Two successive bacterial applications were made a week apart. The treatments in the in vivo biocontrol experiment were: Plants inoculated with F. oxysporum and bacteria, Plants inoculated with $F$. oxysporum on its own (Control a) and a non-inoculated control (Control b). The noninoculated control was treated with sterile millet seed without fungal and bacterial inoculum. The plants were irrigated twice daily with tap water by means of an automatic watering system. All the in vitro and in vivo experiments were arranged in a randomized block design in three replications and each experiment was repeated twice.

\subsubsection{Disease assessment}

Four weeks later, plants were removed from the soil and the roots washed with sterile distilled water. Roots were excised from the plants and data collected for analysis. Data included root and crown rot severity assessed on a rating scale of $0-4$ (Brien et al., 1991). 
( $0=$ no infection, $1=1-25 \%$ infection, $2=26-50 \%$ infection, $3=51-75 \%$ infection and $4=76-100 \%$ infection in the root and crown regions. Based on the disease severity index, the percentage suppression of root and crown rot was calculated (VillajuanAbgona et al., 1996) as follows:

$$
\text { \% Suppression }=\left[\frac{(A-B)}{A} \times 100\right],
$$

where, $\mathrm{A}$ is the disease severity exhibited in the root/crown region due to F. oxysporum alone and $\mathrm{B}$ is the disease severity exhibited in the root/crown region after inoculation with both the pathogen and bacterial antagonists. Roots from eight plants per treatment were excised and the fresh and dry weights were determined on four root systems per treatment. The remaining four roots were subsequently used to determine the incidence of F. oxysporum as described below.

\subsubsection{Incidence of Fusarium oxysporum in roots}

For determination of the incidence of $F$. oxysporum in roots, rose-bengal-glycerol-urea (RBGU) medium selective for Fusarium was used (Van Wyk et al., 1986). RBGU medium contains: glycerol $10 \mathrm{ml}$, urea $1.0 \mathrm{~g}$, 1-alanine $0.5 \mathrm{~g}$, PCNB $1 \mathrm{~g}$, rose-bengal $0.5 \mathrm{~g}$, chloramphenicol $0.25 \mathrm{~g}$, and $12 \mathrm{~g}$ bacteriological agar. The agar was dissolved in $1 \mathrm{~L}$ capacity Erlenmeyer flask containing $800 \mathrm{ml}$ distilled water. The other ingredients were dissolved in a small quantity of absolute ethanol and mixed with sterile $200 \mathrm{ml}$ distilled water in a separate flask. This was then added to the sterile agar medium. The resulting RBGU medium was poured into sterile plastic Petri dishes.

Roots from both infected and non-infected plants were excised, surface sterilized with $0.5 \%$ sodium hypochlorite and rinsed five times with sterile water. The roots from all three replications in each treatment were pooled and a sub sample (10 root pieces per plate) aseptically plated in triplicate on RBGU medium. The plates were incubated at $27 \pm 1^{\circ} \mathrm{C}$ for 7 days. The resulting fungal colonies were examined microscopically and the number of root pieces rendering $F$. oxysporum was recorded. 


\subsubsection{Rhizosphere colonization}

The survival of the bacterial isolates in the rhizosphere of the sorghum plants was determined according to a modification of the procedure described by Landa et al. (2004). Plants were carefully removed from the pots and roots were gently shaken to remove all but the tightly adhering soil. One gram of the adhering rhizosphere soil was collected and placed into $9 \mathrm{ml}$ sterile $0.1 \mathrm{M} \mathrm{MgSO}_{4}$ solutions. Serial dilutions of the suspension were vortexed and plated onto King's B or NA medium as described before. The plates were then incubated at $30{ }^{\circ} \mathrm{C}$ for $24 \mathrm{~h}$ after which the developed colonies were counted and the number of CFU/gm of soil calculated.

\subsubsection{Identification of the bacterial isolates}

Based on the results of the preliminary characterization described above, the most promising isolates were selected and further identified to the species level by means of the API identification system assisted by analytical profile index (API) Plus computer software (bioMèrieux ${ }^{\circledR}$ SA, Marcy-l'Etoile, France). Gram positive, endospore forming rods were identified to the species level using API $^{\circledR} 50 \mathrm{CH}$ test strips. Gram negative rod isolates with fermentative reaction in the Hugh and Leifsons $\mathrm{O} / \mathrm{F}$ test were identified using the $\mathrm{API}^{\circledR} 20 \mathrm{E}$ test strip while those with oxidative reaction were identified by the API 20 NE test strip.

\subsubsection{Statistical analysis}

The data were subjected to analysis of variance using SAS-9.1 software (SAS Institute, 2003). Data on the in vitro root colonization and the survival of the bacterial isolates in the rhizosphere were log transformed before subjecting to analysis of variance (ANOVA). Mean values among treatments were compared by the least significant difference (LSD) test and Duncan's Multiple Range (DMR) test at 5\% $(p=0.05)$ level of significance. 


\section{Results}

\subsection{In vitro assays}

Of the 78 isolates tested, 15 originally isolated on the King's B medium resulted in $>$ $30 \%$ inhibition of mycelial growth of F. oxysporum (Table 1). Of those isolated on NA, seven isolates resulted in $\geqslant 30 \%$ growth inhibition of $F$. oxysporum (Table 2 ). The maximum inhibition achieved by any isolate was 66.3\% (KBE9-1) (Table 1). Control plates not treated with the bacterial isolates were completely covered by the phytopathogens showing no inhibition (Table 1 and Table 2). Fungal growth was not inhibited by isolates NAE5-8, NAE5-3, KBE9-3 and NAE4-4 (Fig. 1). In contrast, KBE9-1, NAE2-4, NAE7-1 and KBE7-6 were amongst the most effective isolates against F. oxysporum displaying $63,39,40$, and $56 \%$ inhibition of mycelial growth respectively (Fig. 1; Table 1 and Table 2). The mean mycelial growth inhibition of the most effective bacterial isolates revealed that the inhibition was highly significant $(p=0.05)$.

Table 1.

Inhibition of Fusarium oxysporum mycelial growth on potato dextrose agar and in vitro root colonization of sorghum roots by rhizobacterial isolates originally isolated on King's B medium

\begin{tabular}{|l|l|l|}
\hline Bacterial isolates & Dual culture assay & In vitro root colonization \\
\hline & \% mycelial inhibition & log cfu/cm roots \pm SE $^{\mathbf{B}}$ \\
\hline KBE5-7 & $40.73^{\mathrm{c}^{*}}$ & $5.72 \pm 0.47^{\mathrm{d}}$ \\
\hline KBE2-5 & $38.43^{\mathrm{c}}$ & $5.90 \pm 0.30^{\mathrm{d}}$ \\
\hline KBE4-3 & $37.43^{\mathrm{cd}}$ & $6.96 \pm 0.28^{\mathrm{c}}$ \\
\hline KBE4-4 & $35.66^{\mathrm{cd}}$ & $4.88 \pm 0.19^{\mathrm{fgh}}$ \\
\hline KBE5-1 & $33.83^{\mathrm{cd}}$ & $6.92 \pm 0.28^{\mathrm{c}}$ \\
\hline KBE5-2 & $56.53^{\mathrm{ab}}$ & $7.09 \pm 0.07^{\mathrm{c}}$ \\
\hline KBE5-3 & $12.36^{\mathrm{ef}}$ & $4.32 \pm 0.44^{\mathrm{j}}$ \\
\hline KBE5-4 & $48.86^{\mathrm{bc}}$ & $4.98 \pm 0.07^{\mathrm{fg}}$ \\
\hline KBE6-1 & $17.40^{\mathrm{bc}}$ & $6.99 \pm 0.07^{\mathrm{c}}$ \\
\hline
\end{tabular}




\begin{tabular}{|c|c|c|}
\hline Bacterial isolates & Dual culture assay & In vitro root colonization \\
\hline & $\%$ mycelial inhibition $^{\mathrm{A}}$ & $\log \mathrm{cfu} / \mathrm{cm}$ roots $\pm S E^{B}$ \\
\hline KBE6-2 & $7.06^{\mathrm{f}}$ & $4.80 \pm 0.21^{\text {fghi }}$ \\
\hline KBE6-3 & $42.73^{b c}$ & $8.25 \pm 0.12^{b}$ \\
\hline KBE6-5 & $42.30^{\mathrm{bc}}$ & $5.15 \pm 0.18^{\mathrm{ef}}$ \\
\hline KBE6-8 & $18.06^{\mathrm{ef}}$ & $4.60 \pm 0.13^{\mathrm{hij}}$ \\
\hline KBE7-6 & $56.36^{\mathrm{ab}}$ & $4.58 \pm 0.12^{\mathrm{hij}}$ \\
\hline KBE7-8 & $38.53^{\mathrm{c}}$ & $8.09 \pm 0.11^{b}$ \\
\hline KBE8-2 & $46.70^{\mathrm{bc}}$ & $6.89 \pm 0.19^{\mathrm{c}}$ \\
\hline KBE8-3 & $46.80^{\mathrm{bc}}$ & $9.28 \pm 0.25^{\mathrm{a}}$ \\
\hline KBE9-1 & $66.33^{\mathrm{a}}$ & $9.22 \pm 0.11^{\mathrm{a}}$ \\
\hline KBE9-4 & $22.70^{\mathrm{de}}$ & $7.09 \pm 0.08^{c}$ \\
\hline KBE9-5 & $15.56^{\mathrm{ef}}$ & $5.34 \pm 0.10^{\mathrm{e}}$ \\
\hline KBE9-8 & $41.00^{\mathrm{c}}$ & $4.69 \pm 0.26^{\text {ghi }}$ \\
\hline Control & $0.00^{\mathrm{g}}$ & $4.47 \pm 0.10^{\mathrm{ij}}$ \\
\hline
\end{tabular}

${ }^{\text {A }} \%$ Mycelial inhibition was calculated as $(R-r) / R \times 100$, where $R$ is mycelial growth away from the bacterial colony (the maximum growth of the fungal mycelia), $r$ is mycelial growth towards the bacteria.

${ }^{\mathrm{B}}$ Root colonization expressed as $\log \mathrm{cfu} / \mathrm{cm}$ root after dilution plating of roots on solid media.

* Means with the same letters do not differ significantly $(p=0.05)$ according to the least significance difference (LSD) tests using the GLM procedure.

Table 2.

Inhibition of Fusarium oxysporum mycelial growth on Potato Dextrose Agar and in vitro colonization of sorghum roots by rhizobacterial isolates initially isolated on Nutrient agar (NA) medium 


\begin{tabular}{|c|c|c|}
\hline Bacterial Isolates & Dual culture assay & In vitro root colonization \\
\hline & $\%$ mycelial inhibition $^{\mathrm{A}}$ & $\log \mathrm{cfu} / \mathrm{cm}$ roots $\pm \mathrm{SE}^{\mathrm{B}}$ \\
\hline NAE1-7 & $33.20^{\mathrm{abcd} *}$ & $7.35 \pm 0.18^{\mathrm{b}}$ \\
\hline NAE2-1 & $19.30^{\mathrm{def}}$ & $7.37 \pm 0.18^{\mathrm{b}}$ \\
\hline NAE2-2 & $19.73^{\text {def }}$ & $7.16 \pm 0.20^{\mathrm{bc}}$ \\
\hline NAE2-4 & $39.06^{\mathrm{ab}}$ & $6.75 \pm 0.13^{\mathrm{cd}}$ \\
\hline NAE2-6 & $22.96^{\text {cdef }}$ & $7.30 \pm 0.21^{b}$ \\
\hline NAE2-8 & $35.23^{\mathrm{abc}}$ & $4.89 \pm 0.17^{\mathrm{g}}$ \\
\hline NAE3-1 & $14.00^{\mathrm{f}}$ & $4.86 \pm 0.10^{g}$ \\
\hline NAE3-3 & $26.00^{b-f}$ & $6.99 \pm 0.16^{\mathrm{bcd}}$ \\
\hline NAE3-6 & $27.6^{\mathrm{a}-\mathrm{f}}$ & $4.64 \pm 0.16^{\mathrm{gh}}$ \\
\hline NAE3-8 & $22.03^{\text {cdef }}$ & $4.64 \pm 0.29^{\mathrm{gh}}$ \\
\hline NAE4-1 & $29.56^{\mathrm{a}-\mathrm{f}}$ & $5.52 \pm 0.31^{\mathrm{f}}$ \\
\hline NAE4-2 & $21.0^{\text {cdef }}$ & $7.27 \pm 0.22^{\mathrm{b}}$ \\
\hline NAE4-4 & $31.33^{\mathrm{a}-\mathrm{e}}$ & $6.05 \pm 0.06^{\mathrm{e}}$ \\
\hline NAE5-5 & $37.46^{\mathrm{ab}}$ & $5.90 \pm 0.13^{\text {ef }}$ \\
\hline NAE5-7 & $26.86^{\mathrm{a}-\mathrm{f}}$ & $7.13 \pm 0.27^{\mathrm{bcd}}$ \\
\hline NAE5-8 & $28.20^{\mathrm{a}-\mathrm{f}}$ & $4.70 \pm 0.12^{\mathrm{gh}}$ \\
\hline NAE6-2 & $30.00^{\mathrm{a}-\mathrm{e}}$ & $8.98 \pm 0.09^{\mathrm{a}}$ \\
\hline NAE6-3 & $21.56^{\text {cdef }}$ & $4.98 \pm 0.61^{\mathrm{g}}$ \\
\hline NAE7-1 & $40.93^{\mathrm{a}}$ & $6.66 \pm 0.43^{d}$ \\
\hline NAE7-2 & $20.43^{\mathrm{def}}$ & $5.92 \pm 0.12^{\text {ef }}$ \\
\hline NAE7-3 & $18.76^{\mathrm{def}}$ & $7.13 \pm 0.02^{\mathrm{bcd}}$ \\
\hline NAE9-3 & $29.33^{\mathrm{a}-\mathrm{e}}$ & $4.76 \pm 0.29^{\mathrm{gh}}$ \\
\hline NAE9-5 & $28.93^{\mathrm{a}-\mathrm{e}}$ & $5.93 \pm 0.19^{\text {ef }}$ \\
\hline Control & $0.00^{\mathrm{g}}$ & $4.37 \pm 0.26^{\mathrm{h}}$ \\
\hline
\end{tabular}


A \% Mycelial inhibition was calculated as $(R-r) / R \times 100$ where $R$ is mycelial growth away from the bacterial colony (the maximum growth of the fungal mycelia), $r$ is mycelial growth towards the bacteria.

${ }^{B}$ Root colonization expressed as $\log \mathrm{cfu} / \mathrm{cm}$ root after dilution plating of roots on solid media.

* Means with the same letters do not differ significantly $(p=0.05)$ according to the least significance difference (LSD) tests using the GLM procedure.
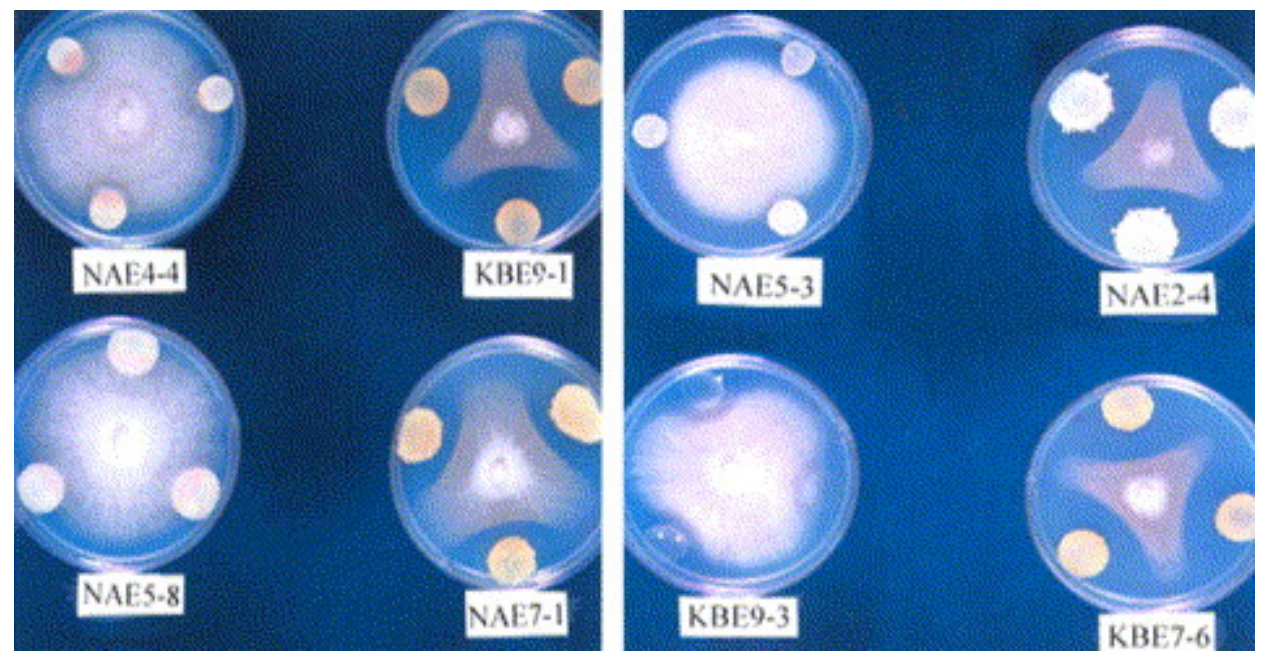

Fig. 1. Dual culture assay for in vitro inhibition of mycelial growth of $F$. oxysporum by selected bacteria isolates. Note the formation of clearly visible inhibition zones on the plates with bacterial isolates KBE9-1, KBE7-6, NAE7-1, and NAE2-4 compared to the plates with isolates NAE4-4, NAE5-8, NAE5-3, and KBE9-3 which resulted in little or no inhibition zones.

The in vitro root colonization study demonstrated that some of the isolates are more effective root colonizers than others. After four days of germination, the bacterial cell counts obtained from the roots have increased by $1.28 \mathrm{log} \mathrm{cfu} / \mathrm{cm}$ root for isolate KBE8-3 and by $1.22 \log \mathrm{cfu} / \mathrm{cm}$ root for isolate KBE9-1 (Table 1) as compared to the control where counting was of $10^{4} \mathrm{cfu} / \mathrm{cm}$ root length from the initial inoculum level of $1 \times 10^{8} \mathrm{cfu} / \mathrm{ml}$ (Table 1). Similarly, isolate NAE6-2 colonized the roots and the count, compared to the initial inoculum level increased by $0.98 \log \mathrm{cfu} / \mathrm{cm}$ root length (Table 2). For most isolates however, the count decreased from the initial inoculum level to up to $10^{4} \mathrm{cfu} / \mathrm{cm}$ root length. Control plates inoculated with sterile distilled water rendered less 
than 30 colonies per plate indicating a low number of bacterial cells which presumably originated from the seed.

\subsection{Greenhouse experiment}

Results from the greenhouse pot experiment demonstrated that KBE5-7, KBE5-1, NAE55 and KBE 2-5 isolates significantly inhibited root and crown rot of sorghum caused by F. oxysporum. (Table 3). These treated plants looked healthy showing no symptoms of root or crown rot (Fig. 2). Isolates KBE4-3, NAE5-7 and KBE5-4 and KBE9-1 resulted in more than $80 \%$ suppression of root rot whilst isolates KBE8-3, KBE5-2 and NAE6-2 resulted in disease reduction of more than $75 \%$ (Table 3). Control plants not treated with bacteria but inoculated with $F$. oxysporum alone rendered up to $100 \%$ root rot incidence with the majority of plants completely stunted or dead (Fig. 2, control a). Plants inoculated with neither the pathogen nor the bacterial isolates also survived but rendered some infection (Fig. 2, Table 3). This could probably be due to a low level of cross contamination by some Fusarium survival in the steam pasteurized soil, but internal contamination is unlikely in this case.

Table 3.

Effect of inoculated rhizobacteria on suppression of Fusarium oxysporum root and crown rot in sorghum under greenhouse conditions

\begin{tabular}{|l|l|l|l|l|}
\hline Treatment & Disease suppression (\%) & \multicolumn{2}{l|}{ Root biomass (g) } \\
\hline & Root & Crown & Fresh weight & Dry weight \\
\hline NAE9-5 & $13.68^{\text {ef* }^{\text {f }}}$ & $16.33^{\text {fg* }}$ & $0.046^{\text {gh* }}$ & $0.007^{\text {gh* }}$ \\
\hline NAE9-3 & $42.05^{\text {de }}$ & $42.35^{\text {def }}$ & $0.043^{\text {gh }}$ & $0.010^{\text {fgh }}$ \\
\hline NAE7-1 & $45.74^{\text {cde }}$ & $43.91^{\text {def }}$ & $0.073^{\text {fgh }}$ & $0.016^{\text {defg }}$ \\
\hline NAE2-1 & $55.98^{\text {bcd }}$ & $30.66^{\text {ffg }}$ & $0.060^{\text {fgh }}$ & $0.013^{\text {efgh }}$ \\
\hline KBE7-6 & $57.25^{\text {bcd }}$ & $45.56^{\text {def }}$ & $0.083^{\text {d-h }}$ & $0.010^{\text {fgh }}$ \\
\hline KBE9-8 & $60.43^{\text {abcd }}$ & $44.53^{\text {def }}$ & $0.096^{\text {c-g }}$ & $0.016^{\text {defg }}$ \\
\hline NAE2-4 & $61.15^{\text {abcd }}$ & $57.11^{\text {cde }}$ & $0.106^{\text {b-g }}$ & $0.030^{\text {bc }}$ \\
\hline NAE1-7 & $59.93^{\text {abcd }}$ & $44.99^{\text {def }}$ & $0.053^{\text {fgh }}$ & $0.010^{\text {fgh }}$ \\
\hline
\end{tabular}




\begin{tabular}{|c|c|c|c|c|}
\hline \multirow[t]{2}{*}{ Treatment } & \multicolumn{2}{|c|}{ Disease suppression (\%) } & \multicolumn{2}{|c|}{ Root biomass (g) } \\
\hline & Root & Crown & Fresh weight & Dry weight \\
\hline KBE6-3 & $68.00^{\mathrm{abcd}}$ & $45.45^{\mathrm{def}}$ & $0.100^{\mathrm{c}-\mathrm{g}}$ & $0.015^{\text {defg }}$ \\
\hline KBE8-2 & $71.08^{\mathrm{abcd}}$ & $94.47^{\mathrm{a}}$ & $0.153^{\mathrm{abcd}}$ & $0.023^{\text {bcde }}$ \\
\hline KBE7-8 & $71.71^{\mathrm{abcd}}$ & $59.86^{\text {bcde }}$ & $0.096^{\mathrm{c}-\mathrm{g}}$ & $0.023^{\text {bcde }}$ \\
\hline KBE8-3 & $76.34^{\mathrm{abcd}}$ & $56.97^{\text {cde }}$ & $0.173^{\mathrm{abc}}$ & $0.026^{\mathrm{bcd}}$ \\
\hline NAE6-2 & $78.32^{\mathrm{abcd}}$ & $81.07^{\mathrm{abc}}$ & $0.110^{\mathrm{b}-\mathrm{g}}$ & $0.016^{\text {defg }}$ \\
\hline KBE5-2 & $77.57^{\text {abcd }}$ & $25.55^{\mathrm{fg}}$ & $0.060^{\text {fgh }}$ & $0.010^{\text {fgh }}$ \\
\hline KBE5-4 & $86.22^{\mathrm{ab}}$ & $78.99^{\mathrm{abc}}$ & $0.083^{\mathrm{d}-\mathrm{h}}$ & $0.013^{\text {efgh }}$ \\
\hline KBE9-1 & $84.45^{\mathrm{abc}}$ & $90.77^{\mathrm{ab}}$ & $0.053^{\text {fgh }}$ & $0.016^{\text {defg }}$ \\
\hline KBE4-3 & $95.53^{\mathrm{ab}}$ & $86.74^{\mathrm{abc}}$ & $0.043^{\text {gh }}$ & $0.016^{\mathrm{defg}}$ \\
\hline NAE5-7 & $95.83^{\mathrm{ab}}$ & $95.83^{\mathrm{a}}$ & $0.130^{\mathrm{a}-\mathrm{f}}$ & $0.026^{\text {bcd }}$ \\
\hline KBE5-7 & $100^{\mathrm{a}}$ & $100^{\mathrm{a}}$ & $0.120^{\mathrm{a}-\mathrm{g}}$ & $0.030^{\mathrm{bc}}$ \\
\hline KBE5-1 & $100^{\mathrm{a}}$ & $100^{\mathrm{a}}$ & $0.190^{\mathrm{a}}$ & $0.030^{\mathrm{bc}}$ \\
\hline NAE5-5 & $100^{\mathrm{a}}$ & $100^{\mathrm{a}}$ & $0.140^{\mathrm{a}-\mathrm{e}}$ & $0.020^{\text {cdef }}$ \\
\hline KBE2-5 & $100^{\mathrm{a}}$ & $100^{\mathrm{a}}$ & $0.126^{\mathrm{a}-\mathrm{f}}$ & $0.033^{\mathrm{b}}$ \\
\hline Control b & $71.19^{\mathrm{abcd}}$ & $69.06^{\mathrm{abcd}}$ & $0.183^{\mathrm{ab}}$ & $0.046^{\mathrm{a}}$ \\
\hline Control a & $0.00^{\mathrm{f}}$ & $0.00^{\mathrm{g}}$ & $0.010^{\mathrm{h}}$ & $0.001^{\mathrm{h}}$ \\
\hline $\mathrm{LSD}_{0.05}$ & 40.33 & 32.29 & 0.079 & 0.012 \\
\hline
\end{tabular}

${ }^{\mathrm{A}}$ Percent disease suppression was determined as $[\mathrm{A}-\mathrm{B} / \mathrm{A}] \times 100$, where $\mathrm{A}$ is disease severity index in the root/crown of control plants inoculated with only Fusarium oxysporum without bacterial antagonists, B is disease severity index in the root/crown of plants treated with both the pathogen and bacterial antagonists.

${ }^{*}$ Means with different letters are significantly different at $p=0.05$ according to the Least Significance Difference (LSD) $t$ test using the GLM procedure in SAS-9.1 software. 


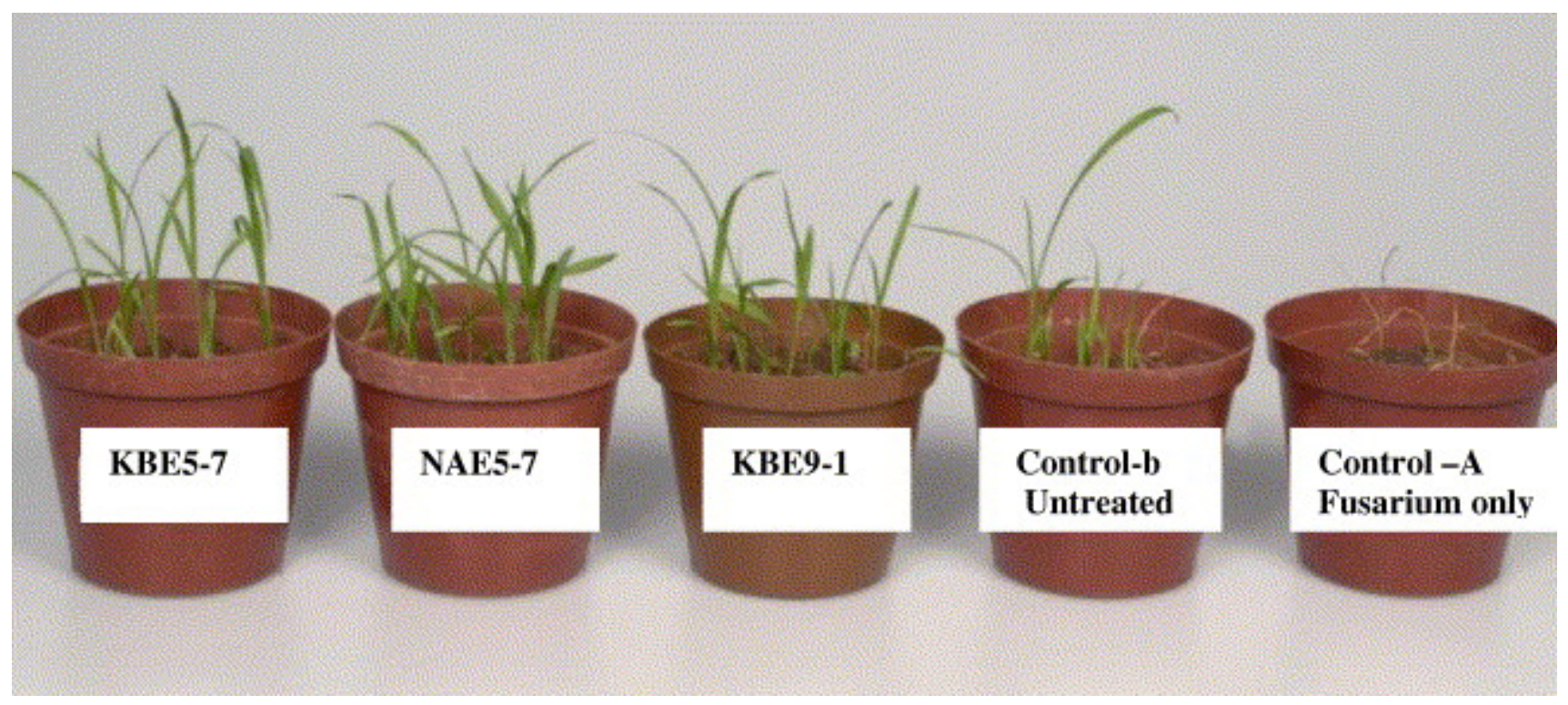

Fig. 2. Greenhouse pot experiment illustrating the efficacy of some of the bacterial isolates in the suppression of root and crown rot diseases by F. oxysporum in four weeks old sorghum seedlings. All plants treated with F. oxysporum alone died (Control a, far right) whereas $100 \%$ of the plants inoculated with both the pathogen and isolates KBE57, NAE5-7, and KBE9-1 survived with no symptoms of infection.

All infected roots were characterized by dark red to black discoloration and rotting. The leaves of infected seedlings were pale green and plants were stunted (ig. 2). The fungus resulted in a pronounced decrease in the fresh and dry weight of the roots compared to the non inoculated control and to some of the treatments with the most effective bacterial isolates. The reduction in fresh weight of roots amounted to $94.4 \%$ in the control treatment inoculated with $F$. oxysporum alone, whereas 33\% reduction in fresh root weight was recorded for the treatments inoculated with both the pathogen and isolates KBE2-5 and KBE5-7. The least reduction in fresh root weight (5.5\%) was recorded for the treatment inoculated with KBE8-3. Interestingly however, a 5.2\% increase in fresh root weight was recorded with isolate KBE5-1, one of the effective isolates that prevented root and crown rot in this study (Table 3).

Root dry weight of the control treatment inoculated with only F. oxysporum decreased by $97.8 \%$ in relation to the non-inoculated control. Among the potential biological control agents in this study, isolates KBE5-1 and KBE9-1 resulted in 34.8 and $65.2 \%$ reduction 
in root dry weight respectively compared to the $97.8 \%$ reduction recorded for the control inoculated with $F$. oxysporum alone.

Percentage of roots of sorghum plants showing presence of $F$. oxysporum in the various treatments showed a reduction of the fungus by some of the bacterial isolates ranging from $60-87 \%$ (Fig. 3). Almost $100 \%$ of the roots from the control treatment (F. oxysporum only) rendered growth of $F$. oxysporum compared to an incidence ranging from 13.3 to $53.3 \%$ for plants treated with isolates KBE5-7, NAE5-5, KBE4-3, KBE9-1, KBE5-1, NAE5-7 and KBE2-5, KBE7-8, and KBE8-3 (Fig. 3).

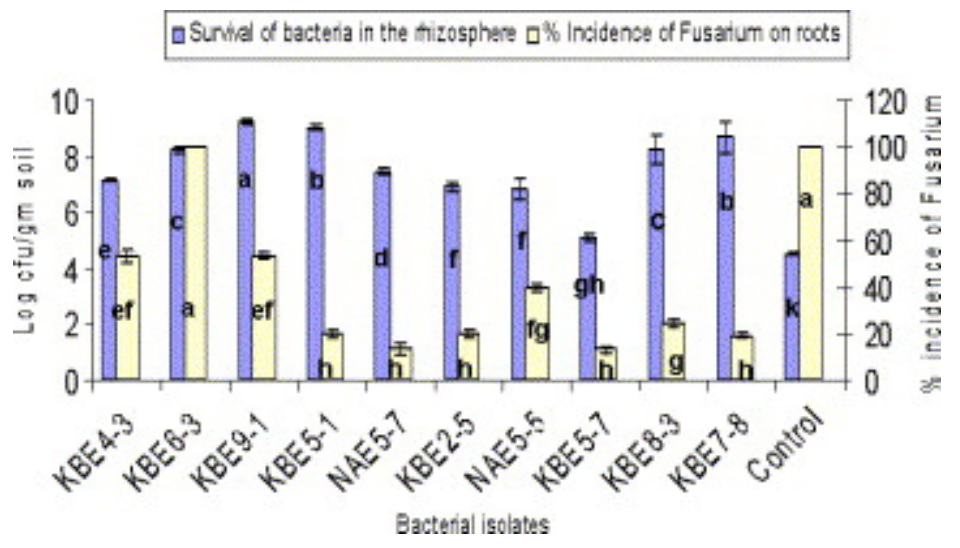

Fig. 3. Efficacy of the bacterial isolates as biological control agents in sorghum as illustrated by their high rate of survival in the rhizosphere and low incidence of $F$. oxysporum in roots four weeks after inoculation with both the bacterial isolates and the target pathogen. Bars represent standard errors of differences of means. Means with the same letter are not significantly different according to Duncan's Multiple Range Test $(p=0.05)$ using the GLM procedure.

\subsection{Identification of bacterial isolates}

According to the results of the API tests, $80 \%$ of the bacteria tested belong to members of the Genus Bacillus where $45 \%$ correspond to Bacillus cereus. The rest of the Bacillus species were identified as Bacillus subtilis, B. licheniformis, B. circulans and B. stearothermophilus. Two Gram negative isolates were identified as Chromobacterium violaceum (Table 4). 
Table 4.

Identification to the species level of the most effective bio-control isolates obtained from sorghum rhizosphere in Ethiopia

\begin{tabular}{|c|c|c|c|c|c|c|c|}
\hline $\begin{array}{l}\text { Bacterial } \\
\text { Isolates }\end{array}$ & $\begin{array}{l}\text { Gram } \\
\text { reaction }\end{array}$ & $\begin{array}{l}\text { Endo- } \\
\text { spore }^{\text {a }}\end{array}$ & $\begin{array}{l}\text { Catalase } \\
\text { test }\end{array}$ & $\begin{array}{l}\text { Cytochrome } \\
\text { oxidase }\end{array}$ & Motility $^{b}$ & Oxidation/Fermentation(O/F) & $\begin{array}{l}\text { API }{ }^{\circledR} \text { identification } \\
\text { (bioMèrieux) }\end{array}$ \\
\hline KBE5-7 & + & + & + & - & + & $\mathrm{Nd}$ & $\begin{array}{l}\text { Bacillus } \\
\text { stearothermophilus }\end{array}$ \\
\hline $\mathrm{KBE} 4-3$ & + & + & + & + & + & $\mathrm{Nd}$ & Bacillus cereus \\
\hline KBE5-1 & + & + & + & + & + & $\mathrm{Nd}$ & Bacillus cereus \\
\hline KBE6-3 & + & + & + & + & - & $\mathrm{Nd}$ & Bacillus subtilis \\
\hline KBE7-6 & + & + & + & - & + & $\mathrm{Nd}$ & Bacillus lecheniformis \\
\hline KBE7-8 & + & + & + & + & + & $\mathrm{Nd}$ & Bacillus cereus \\
\hline KBE9-1 & - & - & + & + & + & Oxidative & $\begin{array}{l}\text { Chromobacterium } \\
\text { violaceum }\end{array}$ \\
\hline NAE5-5 & + & + & + & + & + & $\mathrm{Nd}$ & Bacillus cereus \\
\hline NAE5-7 & + & + & + & + & & $\mathrm{Nd}$ & Bacillus circulans \\
\hline KBE8-3 & + & + & + & - & + & $\mathrm{Nd}$ & Bacillus cereus \\
\hline KBE8-2 & - & - & + & + & + & Oxidative & $\begin{array}{l}\text { Chromobacterium } \\
\text { violaceum }\end{array}$ \\
\hline KBE2-5 & + & + & + & + & + & $\mathrm{Nd}$ & Bacillus spp. \\
\hline
\end{tabular}

a + , endospore present; -, endospore absent.

${ }^{\mathrm{b}}+$, motile; -, non motile; $\mathrm{Nd}$, not done. 


\section{Discussion}

The aim of this study was the screening and selection of rhizobacteria inoquous to sorghum plants with antagonistic activity against $F$. oxysporum associated with root and crown rot in sorghum. The pathogenecity test conducted (data not shown) revealed that $F$. oxysporum isolate RC331 is the most virulent isolate against sorghum. The millet seed inoculum used at a rate of $30 \mathrm{~g} / \mathrm{kg}$ was sufficient for the pathogen to grow and cause infection in a few days. The rest of the F. oxysporum isolates tested didn't show similar effects even if applied at higher concentrations. This could have resulted from the ability of F. oxysporum isolate RC331 to sporulate so quickly (7-10 days) than the other strains which took quite longer periods.

The approach was hence to begin screening the bacterial isolates for their in vitro biocontrol activity against $F$. oxysporum and in vitro root colonization ability. The bacterial isolates used were initially isolated from the rhizosphere of sorghum plants in the major sorghum growing fields in Ethiopia. The approach provided an opportunity to select effective biocontrol strains capable of antagonizing soilborne pathogens in the same environment where they will be used commercially (Landa et al., 1997). Moreover, isolation of bacteria from within the rhizosphere of the target crop is essential for successful identification of potential biocontrol agents (Williams and Asher, 1996). It is known that in vitro assays have certain limitations in that the biocontrol efficiencies may not be equally expressed under gnotobiotic (axenic) and in vivo conditions (Inam-ulHaq et al., 2003). However, the in vitro assays conducted in our study (pathogen inhibition and root colonizing ability) were used to screen and select potential biocontrol agents and subsequently test their ability to suppress Fusarium root rot of sorghum under greenhouse conditions.

The percentage of in vitro mycelial growth inhibition by the rhizobacterial isolates against F. oxysporum varied between $7.06 \%$ and $66.3 \%$ (Table 1 and Table 2). Some bacterial isolates were found to be highly inhibitory of $F$. oxysporum growth whereas others showed only mild activity or no activity at all (Fig. 1). This suggests that the mode of action exerted and/or the type of antifungal metabolite produced by the isolates may vary (Williams and Asher, 1996) but also that the bacterial isolates are taxonomically different from each other (Williams and Asher, 1996). 
For the isolates that caused prominent inhibition of fungal growth in the dual culture experiment, the inhibition zone formed was of such size that there was no physical contact with the pathogens (Fig. 1) suggesting that the rhizobacteria could be producing certain antifungal metabolites (AFMs) (Montealegre et al., 2003). Moreover, as the PDA medium used for the dual culture assay is rich in nutrients, competition might be excluded as the mode of action for these isolates (Landa et al., 1997). The antifungal metabolites produced seem to vary among the isolates tested in this study. In the dual culture assay for instance, some of the isolates not only inhibited the mycelial growth but also changed the appearance of the mycelia from white to reddish brown and red as was evident for isolates KBE9-1, NAE7-1, NAE2-4 and KBE7-6 (Fig. 1). This suggests that the fungal mycelia might have been inhibited not only by antibiosis but also by other antifungal metabolites such as siderophores, hydrogen ions and gaseous products including ethylene, hydrogen cyanide and ammonia (Williams and Asher, 1996, Kumar et al., 2002 and Saravanan et al., 2004). Furthermore, the efficacy of a given biological control agent mostly results, not only from a single mechanism but from a combination of different modes of actions (Alabouvette et al., 1993).

In most bio-control investigations, a large number of antagonists are commonly isolated in a short period of time and screened in vitro for antagonistic activity. However, tests based on in vitro mycelial inhibition and root colonization do not always correlate with biocontrol efficacy under natural conditions (Paulitz et al., 1992 and Williams and Asher, 1996). All promising isolates from the current study were therefore further evaluated under greenhouse conditions.

The bacterial isolates which showed significant in vitro root colonization also colonized the sorghum rhizosphere effectively in the greenhouse experiment (Fig. 3). Isolates KBE7-8, KBE8-3 and KBE6-3 maintained their initial level of population up to 30 days after inoculation (Fig. 3). These results concur with those of others researchers (Sorenson et al., 2001) who reported that a culture based approach such as this can be an important tool to evaluate root colonizing bacterial communities.

Due to the large number of bacteria tested in the current study, a separate inoquity test of the bacterial isolates on sorghum was not conducted. However, all the isolates applied at 
an inoculum level of $10^{8} \mathrm{cfu} / \mathrm{ml}$ and that inhibited the pathogen significantly didn't exhibit any negative effect on the sorghum.

The effective colonization of sorghum roots by isolates such as KBE9-1, KBE5-1, NAE5-5, and KBE5-7 (Table 1 and Table 2) might have contributed to their capability to inhibit infection of sorghum roots by F. oxysporum and reduce root and crown rot. All four bacterial isolates inhibited F. oxysporum both in the dual culture assay and in the greenhouse experiments.

Nevertheless, some isolates behaved differently in the in vitro and in vivo experiments. This was particularly true for isolates KBE9-8, NAE7-1, and NAE2-4 which rendered a $40 \%$ mycelial inhibition of $F$. oxysporum in the dual culture experiment (Table 1 and Table 2, Fig. 1). Whereas under greenhouse conditions in this study, these isolates achieved relatively low population levels of $<10^{5} \mathrm{cfu} / \mathrm{gm}$ in the rhizosphere. This population is below the threshold value for a biological control agent to successfully compete in the rhizosphere (Raaijmakers and Weller, 2001). Ownley et al. (2003) have indicated that such differences result from variability in the physical and chemical properties within niches occupied by bio-control agents which in turn affect both colonization and expression of bio-control mechanisms.

Among the potential biocontrol agents active in the rhizosphere, several members of the Genus Bacillus are reported to be effective in controlling a variety of fungal plant diseases (Williams and Asher, 1996, Landa et al., 1997 and Commare et al., 2002). Most of these agents were able to inhibit the mycelial growth of $F$. oxysporum effectively in vitro. A diversity of pathogenic F. oxysporum isolates including F. o. ciciris, F. o. phasioli, and F. o. melonies have been successfully suppressed by Bacillus spp. isolated from chickpea rhizosphere (Landa et al., 1997).

Similarly, in the current study, the majority of the isolates showing significant bio-control activity belong to members of the genus Bacillus of which $45 \%$ are Bacillus cereus (Table 4). The Bacillus cereus strains KBE4-3, KBE5-1, KBE7-8, KBE8-3, and NAE5-5 have dominated the natural biocontrol population in the rhizosphere of sorghum in this study. All five isolates have significantly inhibited $F$. oxysporum in vitro and in the greenhouse (Table 1, Table 2 and Table 3 and Fig. 3) and have potential as biocontrol agents in sorghum rhizosphere. A strain of Bacillus cereus UW85 has previously been 
reported to suppress plant diseases caused by Oomycetes (Silo-Suh et al., 1994 and Handelsman and Stabb, 1996) due to the production of the antibiotics Zwittermicine (Milner et al., 1996a) and Kanosamine (Milner et al., 1996b). Indirect promotion of plant growth occurs when PGPR lessen or prevent the deleterious effects of phytopathogens through mechanisms such as antibiosis against the pathogens (Asghar et al., 2004). Elizabeth and Handelsman (1999) suggested that the effect of Bacillus cereus on the microbial community in the rhizosphere is perhaps exerted by stimulating growth of other bacteria that stimulate root growth, antagonize the pathogen or induce resistance in the host.

Isolate KBE6-3 which resulted in 68\% suppression of Fusarium root rot (Table 3) was identified as Bacillus subtilis. B. subtilis also occurs in the soil surrounding the root and has often been reported as an antifungal agent against plant pathogens (Marten et al., 2000; Bais et al., 2004). Fusarium wilt of chickpea caused by F. oxysporum f.sp.ceciris has been suppressed by $B$. subtilis isolate GBO3 (Hervas et al., 1998). The same $B$. subtilis isolate has also been reported to activate an ISR pathway in Arabidopsis by the production of some volatiles (Compant et al., 2005). Bochow et al. (1995) demonstrated that certain root colonizing strains of $B$. subtilis play a role as biocontrol agents through induced tolerance of treated seedlings against attack by F. oxysporum. In another experiment (Basha and Ulaganathan, 2002) lysis and dissolution of fungal mycelium of Aspergillus niger strain have been associated with the chitinolytic property of Bacillus subtilis strain AF1.

Among the other promising isolates identified as members of the Genus Bacillus in this study are isolate KBE7-6 identified as B. licheniformis, isolate NAE5-7 identified as B. circulans and isolate KBE5-7 identified as B. stearothermophilus. One of the mechanisms by which Bacillus species exert their antagonistic activity against fungal pathogens is parasitism which operates by degradation of cell walls of pathogenic fungi. In this regard, both B. circulans (Watanabe et al., 1990) and B. licheniformis (Trachuk et al., 1996) produce the enzyme chitinase that degrade chitin. Because of their ability to degrade chitin, the major structural component of the cell walls of phytopathogenic fungi (Someya et al., 2004), chitinolytic enzymes are considered important in the biological control of soilborne pathogens (Singh et al., 1999). 
In the current study, isolates KBE9-1 and KBE8-2 which were characterized by the production of a violet to reddish pigment on agar media were identified by the API as $C$. violaceum (Table 4). Both isolates were able to colonize sorghum roots at a level higher than the required threshold level and were also able to inhibit F. oxysporum in vitro and in vivo. Chitinolytic enzymes produced by $C$. violaceum have been shown to be involved in the biological control of F. oxysporum (Park et al., 1995). A strain of C. violaceum ATCC 12472 (Chernin et al., 1998) selected from a variety of chitin utilizing bacterial species has previously been reported as the most active chitin degrading isolate. Although C. violaceum usually constitute only a small proportion of the total micro-flora in soil, the ability of certain strains to produce antibiotics, hydrogen cyanide, proteases and a number of chitinolytic enzymes (Chernin et al., 1998) indicates that $C$. violaceum have the potential as biological control agents.

Results from the dual culture assay together with the morphological and biochemical characterization of the bacteria using the API system indicated that the selected rhizobacterial isolates are taxonomically different from each other. There is thus a possibility of using these isolates to control other Fusarium isolates which are pathogenic to sorghum and other crops.

Currently investigations are being conducted to determine the modes of actions of all the promising isolates from this study. To determine whether these promising strains can be developed into commercial inoculants, their biocontrol efficacy must first be confirmed under field conditions.

\section{References}

Alabouvette et al., 1993 C. Alabouvette, P. Lemanceau and C. Steinberg, Recent Advances in the biological control of fusarium wilts, Pest. Sci. 37 (1993), pp. 365-373. Asghar et al., 2004 H.N. Asghar, Z.A. Zahir and M. Arshad, Screening rhizobacteria for improving the growth, yield and oil content of canola (Brassica napus L.), Aust. J. Agr. Res. 55 (2004), pp. 187-194.

Basha and Ulaganathan, 2002 S. Basha and K. Ulaganathan, Antagonism of Bacillus species (strain BC121) towards Curvularia lunata, Curr. Sci. 82 (2002), pp. 1457-1463. 
Benhamou, 1992 N. Benhamou, Ultrastructural and cytochemical aspects of chitosan on Fusarium oxysporum f.sp.radicis-lycopersici, agent of tomato crown and root rot, Cytology and Histology 82 (1992), pp. 1185-1193.

Bais et al., 2004 H.P. Bais, R. Fall and J.M. Vivanco, Biocontrol of Bacillus subtilis against infection of Arabidopsis roots by Pseudomonas syringae is facilitated by biofilm formation and surfactin production, Plant Physiol. 134 (2004), pp. 307-319.

Bloemberg and Lugtenberg, 2001 G.V. Bloemberg and B.J.J. Lugtenberg, Molecular basis of plant growth promotion and biocontrol by rhizobacteria, Curr. Opin. Plant Biol. 4 (2001), pp. 343-350.

Bochow et al., 1995 Bochow, H., Dolej., S.T., Fischer, I., Melkamu., A., 1995. Plant health promoting effects by Bacillus subtilis and its modes of actions. In: Lyr., Russel., Sisler, (Eds). Modern Fungicides and Antifungal Compounds. Proceedings of the 11th Int. Symp. Intercept Ltd. Andover, Hampshire SP10 1YG, UK. pp. 549-554. Brien et al., 1991 R.G.O. Brien, P.J.O. Hare and R.J. Glass, Cultural practices in the control of bean root rot, Aust. J. Exp. Agr. 30 (1991), pp. 551-555.

Chernin et al., 1998 L.S. Chernin, M.K. Winson, J.M. Thomson, S. Haran, B.W. Bycroft, I. Chet, P. Williams and G.S.A.B. Stewart, activity in Chromobacterium violaceum: substrate analysis and regulation by quorum sensing, J. Bacteriol. 180 (1998), pp. 44354441 .

Commare et al., 2002 R.R. Commare, R. Nandakumar, A. Kandan, S. Suresh, M. Bharthi, T. Raguchanger and R. Samiyappan, Pseudomonas fluorescense based formulation for the management of sheath blight disease and leaf folder insect in rice, Crop Prot. 21 (2002), pp. 671-677.

Compant et al., 2005 S. Compant, B. Duffy, J. Nowak, C. Climent and E.A. Barka, Use of plant growth promoting bacteria for biocontrol of plant diseases: principles, mechanisms of action, and future prospects, Appl. Environ. Microbiol. 71 (2005), pp. 4951-4959.

Elizabeth and Handelsman, 1999 A.B.E. Elizabeth and J. Handelsman, Biocontrol of plant diseases: a (Gram) positive perspective, Febs Microbiol. Letters 171 (1999), pp. 19. 
Food Agricultural Organization, 1999 Food Agricultural Organization. 1999. FAO Quarterly Bulletin of statistics, 12. FAO. Rome Italy.

Forbes et al., 1986 G.A. Forbes, G.N. Odvody and J.M. Terry, Seedling Diseases. In: R.A. Frederikson, Editor, Compendium of Sorghum Diseases, American Phytopathological Society, St. Paul, MN (1986), p. 78.

Gregorson, 1978 G. Gregorson, Rapid method for distinction of Gram-positive bacteria, Eur. J. Appl. Microbiol. 5 (1978), pp. 123-127.

Handelsman and Stabb, 1996 J. Handelsman and E.V. Stabb, Biocontrol of soilborne plant pathogens, The Plant Cell. 8 (1996), pp. 1855-1869.

Hervas et al., 1998 A. Hervas, B. Landa, L.E. Datnoff and R.M. Jimenez-Diaz, Effects of commercial and indigenous microorganisms on Fusarium wilt development in chickpea, Biol. Control. 13 (1998), pp. 166-176.

Huge and Leifson, 1953 R. Huge and H. Leifson, The taxonomic significance of fermentative versus oxidative Gram-negative bacteria, J. Bacteriol. 66 (1953), pp. 24-26. Huluka and Else, 1992 M. Huluka and J.P.E. Else, Sorghum Diseases in Eastern Africa. In: W.J.A. de Millano, R.A. Frederikson, L.K. Mughogo and D.J. Bengstone, Editors, Sorghum and Millet Diseases, ICRISTAT, Pathancheru, India (1992), pp. 36-39. Inam-ul-Haq et al., 2003 M. Inam-ul-Haq, M. Javed, R. Ahmad and A. Rehman, Evaluation of different strains of Pseudomonas fluorescense for the biocontrol of Fusarium wilt of chickpea, Pakistan J. Plant Pathol. 2 (2003), pp. 65-74.

King et al., 1954 E.O. King, M.K. Ward and D.E. Ranney, Two simple media for the demonstration of pyocyanin and fluorescin, J. Lab. Clin. Med. 44 (1954), pp. 301-307. Kloepper et al., 1980 J.W. Kloepper, J. Leong, M. Teintze and M.N. Schroth, Enhanced plant growth by siderophores produced by plant growth promoting rhizobacteria, Nature 268 (1980), pp. 885-886.

Kovacs, 1956 N. Kovacs, Identification of Pseudomonas pyocyanae by the oxidase reaction, Nature 178 (1956), p. 703.

Kumar et al., 2002 N.R. Kumar, V. Thirumalai Arasu and P. Gunasekaran, Genotyping of antifungal compounds producing plant growth promoting rhizobacteria, Pseudomonas fluorescense, Curr. Sci. 82 (2002), pp. 1463-1468. 
Landa et al., 1997 B.B. Landa, A. Hervas, W. Bethiol and R.M. Jimenez-Diaz, Antagonistic activity of bacteria from the chickpea rhizosphere against Fusarium oxysporum f.sp.ciceris, Phytoparasitica 25 (1997), pp. 305-318.

Landa et al., 2004 B.B. Landa, J.A. Navas-Cortes and R.M. Jimenez-Diaz, Influence of temperature on plant-rhizobacteria interactions related to biocontrol potential for suppression of fusarium wilt of chickpea, Plant Pathol. 53 (2004), pp. 341-352. Marten et al., 2000 P. Marten, K. Smalla and G. Berg, Genotypic and phenotypic differentiation of an antifungal biocontrol strain belonging to Bacillus subtilis, J. Appl. Microbiol. 89 (2000), pp. 463-471.

Milner et al., 1996a J.L. Milner, E.A. Stohl and J. Handelsman, Zwittermicin A resistance gene from Bacillus cereus, J. Bacteriol. 178 (1996), pp. 4266-4272.

Milner et al., 1996b J.L. Milner, L.A. Silo-Suh, J.C. Lee, H. He, J. Clardy and J. Handelsman, Production of Kanosamine by Bacillus cereus UW85, Appl. Environ. Microbiol. 60 (1996), pp. 2553-2560.

Montealegre et al., 2003 J.R. Montealegre, Reyes, L.M. Perez, R. Herrera, P. Silva and X. Besoain, Selection of bio-antagonistic bacteria to be used in biological control of Rhizoctonia solani in tomato, Electron J. Biotechnol. 6 (2003), pp. 115-127.

Ownley et al., 2003 B.H. Ownley, B.K. Duffy and D.M. Weller, Identification and manipulation of soil properties to improve the biological control performance of phenazine producing Pseudomonas fluorescense, Appl. Environ. Microbiol. 69 (2003), pp. 3333-3343.

Park et al., 1995 S.K. Park, H.Y. Lee and K.C. Kim, Role of chitinase produced by Chromobacterium violaceum in the suppression of Rhizoctonia damping off, Korean J. Plant Pathol. 11 (1995), pp. 304-311.

Patten and Glick, 2002 C.L. Patten and B.R. Glick, Role of Pseudomonas putida indole acetic acid in development of the host plant root system, Appl. Environ. Microbiol. 68 (2002), pp. 3795-3801.

Paulitz et al., 1992 T.C. Paulitz, T. Zhou and L. Rankin, Selection of rhizosphere bacteria for biological control of Pythium aphanidermatum on hydroponically grown cucumber, Biol. Control 2 (1992), pp. 226-237. 
Raaijmakers and Weller, 2001 J.M. Raaijmakers and D.M. Weller, Exploiting the genotypic diversity of 2, 4-diacetylphloroglucinol producing Pseudomonas spp: Characterization of superior root colonizing P. fluorescense strain Q8r1-96, Appl. Environ. Microbiol. 67 (2001), pp. 2545-2554.

Rangajaran et al., 2003 S. Rangajaran, L.M. Saleena, P. Vasudevan and S. Nair, Biological suppression of rice diseases by Pseudomonas spp. under saline soil conditions, Plant Soil 251 (2003), pp. 73-82.

Saravanan et al., 2004 T. Saravanan, M. Muthusami and T. Marimuthu, Effect of Pseudomonas fluorescense on Fusarium wilt pathogen in banana rhizosphere, J. Biol. Sci. 4 (2004), pp. 192-198.

SAS Institute, 2003 SAS Institute. (2003). 'SAS/STAT Guide for personal computers' SAS institute, Cary, NC.

Silo-Suh et al., 1994 L.A. Silo-Suh, B.J. Lethubridge, S.J. Raffel, H. He, J. Clardy and J. Handelsman, Biological activities of two fungistatic antibiotics produced by Bacillus cereus UW85, Appl. Environ. Microbiol. 60 (1994), pp. 2023-2030.

Singh et al., 1999 P.P. Singh, Y.C. Shin, C.S. Park and Y.R. Chung, Biological control of Fusarium wilt of cucumber by chitinolytic bacteria, Phytopathology 89 (1999), pp. 9299.

Someya et al., 2004 N. Someya, S. Numata, M. Nakajima, A. Hasebe and K. Akutsu, Influence of rice isolated bacteria on chitinase production by the biocontrol bacteria Seratia marcescens strain B-2 and the genetically modified rice epiphytic bacteria, $J$. Gen. Plant Pathol. 70 (2004), pp. 371-375.

Sorenson et al., 2001 J. Sorenson, L.E. Jenson and O. Nybroe, Soil and rhizosphere as habitats for Pseudomonas inoculants: new knowledge on distribution, activity and physiological state derived from micro scale and single cell studies, Plant Soil. 232 (2001), pp. 97-108.

Thomshaw, 1996 L.S. Thomshaw, Biological control of plant pathogens, Curr. Opin. Biotech. 77 (1996), pp. 343-347.

Trachuk et al., 1996 L.A. Trachuk, L.P. Revina, T.M. Shemyakina, G.G. Chestukina and V.M. Stepanov, Chitinases of Bacillus lecheniformis B-6839: isolation and properties, Can. J. Microbiol. 42 (1996), pp. 307-315. 
Van Wyk et al., 1986 P.S. Van Wyk, D.J. Scholtz and O. Los, A selective medium for the isolation of Fusarium spp. from soil debris, Phytophylactica. 18 (1986), pp. 67-69. Villacieros et al., 2003 M. Villacieros, B. Power, M. Sanchez-Contreras, J. Loret, R.I. Oruzebal, M. Martin, F. Franandez-Pinas, I. Bouile, C. Whelan, D.N. Dowling and R. Rivilla, Colonization behaviour of Pseudomonas fluorescens and Sinorhizobium meloti in the alfalfa (Medicago sativa) rhizosphere, Plant Soil 251 (2003), pp. 47-54.

Villajuan-Abgona et al., 1996 R. Villajuan-Abgona, K. Kagayama and M. Hyakumachi, Biocontrol of Rhizoctonia damping-off of cucumber by non pathogenic binucleate Rhizoctonia, Eur. J. Plant Pathol. 102 (1996), pp. 227-235.

Watanabe et al., 1990 T. Watanabe, W. Oyanagi, K. Suzuki and H. Tanaka, Chitinase system of Bacillus circulans WL-12 and importance of Chitinase A1 in chitin degradation, Journal of Bacteriology 172 (1990), pp. 4017-4022.

Williams and Asher, 1996 G.E. Williams and M.J.C. Asher, Selection of rhizobacteria for the control of Pythium ultimum and Aphanomyces cochlioides on sugar-beet seedlings, Crop Prot. 15 (1996), pp. 479-486.

Corresponding author. Fax: +2712420 4588/3960. 